Çukurova Üniversitesi Mühendislik Mimarlık Fakültesi Dergisi, 33(3), ss. 217-224, Eylül 2018

Çukurova University Journal of the Faculty of Engineering and Architecture, 33(3), pp. 217-224, September 2018

\title{
Üniversite Öğrencilerinin Giysi Konfor Özellikleri Konusunda Farkındalıklarının Araştırılması
}

\author{
Ebru ÇORUH ${ }^{* 1}$, Züleyha DEĞİRMENCİ ${ }^{2}$, Pelin ACAR ${ }^{3}$ \\ ${ }^{1}$ Gaziantep Üniversitesi, Güzel Sanatlar Fakültesi, Moda ve Tekstil Tasarım, Gaziantep \\ ${ }^{2}$ Gaziantep Üniversitesi, Mühendislik Fakültesi, Tekstil Mühendisliği, Gaziantep \\ ${ }^{3}$ Gaziantep Üniversitesi, Güzel Sanatlar Fakültesi, Moda ve Tekstil Tasarım, Gaziantep
}

Geliş tarihi: 25.01.2018～Kabul tarihi: 15.10 .2018

$\ddot{\mathbf{O z}}$

Giysi konforu, kullanıcı performansını etkileyen parametrelerden biridir. Giysi konforu konusundaki algı ve değerlendirmeler, ortam sıcaklığı ve bağıl nem gibi çevresel; giysi seçimi ve metabolik oran gibi kişisel etkenlere bağlıdır. Kişilerin algılarındaki farklılık, psikolojik durum, vücudun giysi ve çevre ile olan etkileşimlerini açıklayan fizyolojik faktörler, konforu etkileyen önemli parametreler olarak karşımıza çıkmaktadır. Bu çalışmanın amacı, giysi konfor değerlendirmeleri ile ölçülebilen kumaş özellikleri arasındaki ilişkileri incelemek ve farklı materyal ile yapısal özelliklere sahip kumaşların konforla ilişkili özelliklerini değerlendirmektir. Bu çalışmada 18-24 yaş aralığında farklı bölümlerde eğitim gören 100 adet kız ve erkek üniversite öğrencilerinin giysi konforu beklentileri çok kapsamlı bir anket örneği ile analiz edilmiş ve elde edilen sonuçlar cinsiyet faktörü de esas alınarak istatistiksel paket programı ile analiz edilmiştir. Çalışmanın sonuçlarına göre cinsiyet konfordan bağımsız bir parametredir.

Anahtar Kelimeler: Giysi konforu, Cinsiyet-konfor, Giysi seçim

\section{Investigation of Awareness of University Students about Clothing Comfort Properties}

\begin{abstract}
Clothing comfort is one of the parameters that affect user performance. Sensation and evaluation on clothing comfort, environmental, such as ambient temperature and relative humidity; clothing selection and metabolic rate. Physiological factors that explain the differences in the perceptions of the people, psychological situation, the body's interaction with the clothes and the environment, and the important parameters affecting the comfort. The aim of this study is to examine the relationship between fabric comfort evaluations and measurable fabric properties and to evaluate the comfort-related properties of fabrics with different materials and structural properties. In this study, clothing comfort expectations of 100 university students (girls and boys) studying at different departments and ages between 18-24 years were analyzed with a very comprehensive questionnaire and the results were analyzed by statistical package program based on gender factor. According to the results of the study, gender is an independent parameter.
\end{abstract}

Keywords: Clothing comfort, Gender-comfort, Clothing selection

*Sorumlu yazar (Corresponding author): Ebru ÇORUH, ecoruh@gantep.edu.tr 


\section{GíRiș}

Giysi ile beden ilişkisi değerlendirildiğinde, giysinin insan vücudunun ikinci bir derisi olduğu düşünülmektedir. Günümüzde tüketicilerin kalite ve konfor konularında bilinçlenmeleri doğrultusunda satın almadaki öncelikleri, iyi görünmenin yanı sira iyi hissettiren giysiler olmaktadır [1]

Yaşam kalitesini daima artırma eğiliminde olan tüketiciler için giyim öğeleri, sosyal ve fiziksel refah sağlama, psikolojik ve görsel tatmin aracı olma özelliğine sahiptir [2].

Her tüketicinin giysiden beklentileri farklı olsa da konforun, ortak beklenti noktası olduğunu söylemek mümkündür. Temel olarak termofizyolojik, duyumsal, fiziksel ve psikolojik olarak konfor dört kısma ayrılır. Termofizyolojik konfor ile kumaş yoluyla sıcaklık ve nemin transferini içeren, rahat bir termal durum elde edilmektedir. Duyumsal konfor bir tekstil ürününün, deri ile temasında çeşitli sinirsel duyumların meydana çıkmasıdır. Fiziksel konfor: bir tekstil ürününün, hareket özgürlüğüne gerektiği gibi izin verme kabiliyetidir. Psikolojik konfor: giyenin toplam rahatlı̆̆ına katkıda bulunan sübjektif algıdır [3-4]. Yani, kişi giymiş olduğu giysiden hem fiziksel açıdan rahatlık beklemekte hem de psikolojik açıdan memnun olmayı istemektedir. Giysi konforu, insan yaşam kalitesini yükseltmeye yönelik olduğu için bu konudaki araştırmalar hem araştırmacıların hem de üreticilerin dikkatini çekmekte, konu ile ilgili çalışmaların önemi de artmaktadır.

Yüksek konforlu bir giysinin hareket rahatlı̆̆ 1 , çabuk kuruma, yumuşaklık ve deriyi tahriş etmeme, hafiflik, dayanıklılık, beğenilen bir tutum ve kolay bakım gibi özellikleri de sağlaması beklenmektedir [5].

Literatürde, çeşitli kumaş parametreleri ile giyim konforu algısı arasındaki ilişkiyi analiz etmek amacıyla istatistiksel yöntemler kullanılarak birçok araştırma yapılmıştır. Giyim gereksinimleri üzerine yapılan bir çalışmada, konfor ve üstün fonksiyonel performans gösteren giysiler, tüketiciler tarafından talep edilen ürünler olarak tespit edilmiştir [3]. Deri üzerine yapılan bir çalışmada, deri üst giyiminde, termofizyolojik (1sil) konfor, psikolojik (estetik) konfor, duyumsal (dokunsal) konfor ve vücut hareketi konforuna ilişkin tüketici memnuniyetini belirleyerek elde edilen veriler 1şığında tüketicilerin ürünlerden beklentileri ortaya konulmuştur [6]. Tüketici giyim kalite değerlendirmesi ile ilgili başka bir çalışmada ise, yüksek kaliteli giysi ipuçları ve giysi beklentileri araştırılarak, giyim konusunda tüketicilerin çok yönlü doğası gereği; giysi performansı ve estetik ile dışsal faktörler kaliteli giyinmede tüketiciler açısından önemli parametreler olarak bulunmuştur. Fiyat, dişsal faktörler arasında en yüksek oy alan özellik olmuş fakat giysi konforu, yüksek kaliteli bir giysi ile ilgili beklentiler grubunda yer almamıştır [7]. Diğer bir araştırmacı büyük beden bayan tüketicilere uygulanan anket ile tüketicileri giysi alışverişlerinde figür tipleri ve beden numaralarının ne derece önemli olduğunu incelemişlerdir. Anket bulguları paralelinde belirlenen sonuçlar ve beklentiler değerlendirilmiştir [8]. Örme denim kumaşların tercih edilmesi üzerine bir grup denim giysi kullanıcısıyla denim giysiler üzerine anket çalışması yapılmış ve anket içerisinde verilen ürünlerin geleneksel denim giysiyle benzer özellikleri bulunmaya çalışılmıştır [9].

İnternet üzerinden yapılan alışverişler için tüketicilerin satın alma davranışlarını analiz etmeye yönelik ve kişilerin estetik, marka, konfor, dış etkiler ve fiyat algısını inceleyen bir çok çalışmalar yapılmıştır [10-13].

$\mathrm{Bu}$ çalışmada 18-24 yaş aralığında farklı bölümlerde eğitim gören k1z ve erkek üniversite öğrencilerinin giysi konforu beklentileri çok kapsamlı bir anket örneği ile analiz edilmiş ve elde edilen sonuçlar cinsiyet faktörü de esas alınarak istatistiksel paket programı ile analiz edilmiştir. 


\section{METOD}

\subsection{Katılımcı Özellikleri}

Gaziantep Üniversitesi'nde yapılan çalışmanın amac1, kişilerin giysi tercihlerinde konforun diğer kriterler arasındaki durumu ve kişinin günlük hayatta giysiliklere bağlı olarak karşılaştıkları sorunların belirlenmesidir. Üniversitenin farklı bölümlerinde okuyan lisans düzeyindeki kız-erkek ögrencileriyle (18-24 yaş grubu arasında) giysi konfor özelliklerinin araştırılması için 100 kişilik bir öğrenci grubu üzerinde gerçekleştirilen anket çalışmasında, katılımcıların günlük hayatlarında giysi konfor özelliklerinin önemi, performans1, sorunları ve beklentilerini belirlemeleri istenmiştir. Ankete katılımcıları \%65 kız öğrenci, \%35 erkek öğrenciler oluşturmaktadır. Katılımcıların yaş aralığında çok varyasyon yoktur. Çoğunluk aktif yaşam ve konfor hakkında bilince sahip genç bir gruptan oluşmaktadır. Ankete katılan öğrencilere makale ekinde verilen ve konforla ilgili tanımlamaların yapıldığı bir broşür verilerek ön bilgilendirilmeleri sağlanmıştır.

\subsection{Anket Soruları}

Ankette farklı türde sorular yer almaktadır. Anket sorularının değerlendirilmesinde 3 ve 4 noktalı sübjektif değerlendirme skalası kullanılmıştır. Demografik sorular olarak öğrencilere yaş ve cinsiyet sorulmuştur. Anket içerisinde ise dört bölümde değerlendirme yapılmıştır.

$>$ Giysi seçiminde öğrencilerin konfor özelliğinin öneminin değerlendirmesinde (1=önemli, 2=k1smen önemli, 3=önemsiz),

$>$ Giysi seçiminde öğrencilerin giysilerde aradığı performans özelliğinin tercih sıralamasında (1=her zaman, 2=çoğunlukla, 3=bazen, 4=hiçbir zaman),

> Giysi kullanımında öğrencilerin en sık karşılaştı̆̆ı sorunların sıralaması (1=her zaman, 2=çoğunlukla, 3=bazen, 4=hiçbir zaman),

$>$ Giysi kullanımında öğrencilerin beklentilerinin değerlendirmesi (1=her zaman, 2=çoğunlukla, 3=bazen, 4=hiçbir zaman) skalaları kullanılmıştır.

Ankette verilerin yorumlanmasında SPSS istatistiksel paket programı kullanılmıştır. Anket verilerinin güvenilirliklerini test etmek için Cronbach's alpha güvenilirlik testi uygulanmıştır. İki bağımsız grubun ortalamaların birbirinden farklı olup olmadığını test etmek amacıyla ankette istatistiksel $\mathrm{t}$ testi (Bağımsız Örneklem t-Testi) kullanılmıştır. T-test sonuçları ve katılımcıların giysi özelliklerini subjektif değerlendirme sonuçları grafiklerle analiz edilmiştir.

\section{BULGULAR VE TARTIŞMA}

Konfor ile ilgili parametreler göz önüne alındığında insanların konfor algılarının yanında, giysi seçimi sırasında ortaya çıkan psikolojik ve fizyolojik gibi karmaşı süreçler dikkat çekmektedir. Giysi konforu, başta hammadde olmak üzere iplik yapısal özellikleri, kumaşın kalınlık, gözeneklilik, geçirgenlik, dayanıklılık, elastikiyet, tutum, yüzey, sıvı transferi ve termal direnci gibi fiziksel ve mekanik özelliklerinden etkilenmektedir [14-16].

Anket verileri analiz edilirken sonuçlar öncelikle matematiksel olarak daha sonra ise istatistiksel olarak değerlendirilmiştir. Anket bölümlerine ilişkin matematiksel analiz tabloları Çizelge 1, 2, 3 ve 4'de sırasıyla verilmiştir.

Çizelge 1. Giysi seçiminde öğrencilerin konfor özelliğinin önemini değerlendirmesi

\begin{tabular}{|l|c|c|c|}
\hline Sorular & $\begin{array}{c}\text { Önemli, } \\
\mathbf{\%}\end{array}$ & $\begin{array}{c}\text { Kismen, } \\
\mathbf{\%}\end{array}$ & $\begin{array}{c}\text { Önemsiz, } \\
\mathbf{\%}\end{array}$ \\
\hline Marka & 50 & 44 & 6 \\
\hline Hammadde & 82 & 13 & 5 \\
\hline Fiyat & 68 & 27 & 5 \\
\hline Dayanıklılık & 83 & 14 & 3 \\
\hline Rahatlık & 83 & 16 & 1 \\
\hline $\begin{array}{l}\text { Hava } \\
\text { geçirgenliği }\end{array}$ & 65 & 33 & 2 \\
\hline Kuruma & 55 & 40 & 5 \\
\hline Serin tutma & 70 & 28 & 2 \\
\hline Hafiflik & 69 & 26 & 5 \\
\hline Dökümlülük & 64 & 30 & 6 \\
\hline
\end{tabular}


Çizelge 2. Giysi seçiminde öğrencilerin giysilerde aradığı performans özelliğinin tercih siralamas1

\begin{tabular}{|l|c|c|c|c|}
\hline Sorular & $\begin{array}{c}\text { Her } \\
\text { Zaman, } \\
\mathbf{\%}\end{array}$ & $\begin{array}{c}\text { Çoğunlukla, } \\
\mathbf{\%}\end{array}$ & $\begin{array}{c}\text { Bazen, } \\
\mathbf{\%}\end{array}$ & $\begin{array}{c}\text { Hiçbir } \\
\text { zaman, } \\
\mathbf{\%}\end{array}$ \\
\hline Esneklik & 22 & 44 & 32 & 1 \\
\hline Ter emicilik & 19 & 46 & 32 & 2 \\
\hline Hafiflik & 35 & 54 & 10 & 0 \\
\hline UV Dayanım & 38 & 33 & 20 & 8 \\
\hline Geçirgenlik & 30 & 39 & 24 & 6 \\
\hline Vücuda uygunluk & 69 & 23 & 5 & 2 \\
\hline
\end{tabular}

Çizelge 3. Giysi kullanımında öğrencilerin en sık karșilaștığ 1 sorunların sıralaması

\begin{tabular}{|l|c|c|c|c|}
\hline Sorular & $\begin{array}{c}\text { Her } \\
\text { zaman, } \\
\text { \% }\end{array}$ & $\begin{array}{c}\text { Çoğunlukla, } \\
\text { \% }\end{array}$ & $\begin{array}{c}\text { Bazen, } \\
\text { \% }\end{array}$ & $\begin{array}{c}\text { Hiçbir } \\
\text { zaman, } \\
\mathbf{\%}\end{array}$ \\
\hline Deformasyon & 9 & 11 & 65 & 14 \\
\hline Cilt tahrişi & 8 & 10 & 53 & 28 \\
\hline Serinlik & 12 & 20 & 60 & 7 \\
\hline Sicaklık & 7 & 12 & 61 & 19 \\
\hline Terletme & 33 & 28 & 30 & 8 \\
\hline
\end{tabular}

Çizelge 4. Giysi kullanımında öğrencilerin beklentilerinin değerlendirilmesi

\begin{tabular}{|l|c|c|c|c|}
\hline Sorular & $\begin{array}{c}\text { Her } \\
\text { zaman, \% }\end{array}$ & $\begin{array}{c}\text { Çoğunlukla, } \\
\text { \% }\end{array}$ & Bazen, \% & $\begin{array}{c}\text { Hiçbir } \\
\text { zaman, } \\
\text { \% }\end{array}$ \\
\hline Ter emicilik & 24 & 66 & 7 & 1 \\
\hline $\begin{array}{l}\text { Hava } \\
\text { geçirgenlik }\end{array}$ & 30 & 65 & 3 & 0 \\
\hline $\begin{array}{l}\text { Ter } \\
\text { uzaklaştırma }\end{array}$ & 27 & 68 & 2 & 1 \\
\hline $\begin{array}{l}\text { Nefes } \\
\text { labilirlik }\end{array}$ & 34 & 60 & 3 & 1 \\
\hline Hafiflik & 38 & 58 & 2 & 0 \\
\hline Yumuşak & 28 & 64 & 5 & 1 \\
\hline $\begin{array}{l}\text { Çabuk } \\
\text { kuruma }\end{array}$ & 24 & 58 & 12 & 4 \\
\hline Model & 38 & 52 & 8 & 0 \\
\hline Dikiş & 46 & 50 & 2 & 0 \\
\hline Ergonomi & 51 & 45 & 2 & 0 \\
\hline $\begin{array}{l}\text { Bakım } \\
\text { kolaylığ }\end{array}$ & 42 & 52 & 2 & 1 \\
\hline $\begin{array}{l}\text { Vücuda } \\
\text { uygunluk }\end{array}$ & 51 & 45 & 1 & 0 \\
\hline Isı tutma & 18 & 65 & 14 & 0 \\
\hline Tuşe & 38 & 54 & 6 & 0 \\
\hline Dökümlü & 26 & 54 & 16 & 1 \\
\hline
\end{tabular}

Çizelge 5. Güvenilirlik analizi

\begin{tabular}{|c|c|}
\hline Cronbach's Alpha & Soru sayısı \\
\hline, 773 & 36 \\
\hline
\end{tabular}

Çizelge 1'de görülen giysi seçiminde öğrencilerin cinsiyet ayrımı yapmaksızın konfor özelliğinin önemi değerlendirildiğinde ilk sırada hammadde, rahatlık ve dayanıklılık \%82-83 olarak, serin tutma, fiyat ve hafiflik \%68-70 önemli olarak belirtilmiştir.

Giysi seçiminde öğrencilerin giysilerde aradığ1 performans özelliğinin tercih sıralaması Çizelge 2 verilerine göre incelendiğinde $\% 69$ ile vücuda uygunluk ilk sırada yer almıştır.

Çizelge 3'de verilen cevaplara göre konforla ilişkilendirilmiş sorunların kişiden kişiye değişkenlik gösterdiği sonucu çıkmaktadır.

Çizelge 4'de sunulan giysi beklentileri sonuçları tüketicilerin giysilerden fiziksel açıdan oldukça yüksek beklentiler içinde olduğunu göstermektedir.

Sonuçlar istatistiki olarak değerlendirilmeden önce verilerin güvenilirliklerini test edilmesi gerekir bu nedenle uygulanan Cronbach's alpha güvenilirlik test sonuçları Çizelge 5'de sunulmuştur.

Cronbach's alpha güvenilirlik testi sonucuna göre 36 soru için \%77 tespit edilmiştir. Çalışma sonuçların analizinde kullanılan t-testin yapılabilmesi için gerekli iki varsayım vardır. Bunlardan birincisi değişkenlerin normal dağılımlı olduğudur. \%95 güvenle veriler normal dağılıma sahiptir. T-testi tablosunun ilk kısmındaki F değeri varyansların homojen olup olmadığını test etmek için kullanılır. Çizelgedeki Sig. değeri 0,05'ten küçükse varyanslar homojen değil demektir. Bu durumda Equal variances not assumed satırı kullanılır. Sig. değeri 0,05'ten büyükse varyansların homojen olduğuna karar verilir. Bu tabloda Sig. (2-tailed) değeri gruplar arasında fark olup olmadığını gösteren değerdir. $\mathrm{Bu}$ değer 0,05'ten küçükse gruplar arasında fark olduğuna karar verilir. Eğer bu değer 0,05'ten büyükse karşılaştırılan gruplar arasında anlamlı fark olmadığına karar verilir. Giysi önem derecesi bağımsız örnek t testi Çizelge 6 'da sunulmuştur. 
Cizelge 6. Giysi önem derecesi bağımsız örnek t testi

\begin{tabular}{|c|c|c|c|c|c|c|}
\hline & \multirow{2}{*}{\multicolumn{2}{|c|}{$\begin{array}{l}\text { Varyansların eşitliği için } \\
\text { Levene's testi }\end{array}$}} & \multicolumn{3}{|c|}{ Cinsiyet } \\
\hline & & & & & amaların & i için t-testi \\
\hline & & $\mathrm{F}$ & Sig. & $\mathrm{T}$ & Df & Sig. (2-tailed) \\
\hline \multirow{2}{*}{ Marka } & E.V.A & ,933 & ,336 & $\begin{array}{ll}-, 549 \\
\end{array}$ & 98 &, 584 \\
\hline & E.V.not A. & & &,- 570 & 77,346 & 570 \\
\hline \multirow{2}{*}{ Hammadde } & E.V.A. & 1,757 & ,188 & ,771 & 98 &, 442 \\
\hline & E.V.not A. & & & ,743 & 62,747 & 460 \\
\hline \multirow{2}{*}{ Fiyat } & E.V.A. & 13,546 & ,000 & 2,230 & 98 &, 028 \\
\hline & E.V.not A. & & & 2,003 & 51,930 &, 050 \\
\hline \multirow{2}{*}{ Dayanıklılık } & E.V.A. & 6,726 & 011 & 1,340 & 98 &, 183 \\
\hline & E.V.not A. & & & 1,210 & 52,696 & ,232 \\
\hline \multirow{2}{*}{ Rahatllk } & E.V.A. & 7,712 & 007 & 1,382 & 98 &, 170 \\
\hline & E.V.not A. & & & 1,240 & 51,788 & 221 \\
\hline \multirow{2}{*}{ Hava geçirgenliği } & E.V.A & 5,266 & ,024 & 2,048 & 98 & ,043 \\
\hline & E.V.not A. & & & 1,967 & 62,136 & 054 \\
\hline \multirow{2}{*}{ Kuruma } & E.V.A & 005 & 942 & 2,312 & 98 &, 023 \\
\hline & E.V.not A. & & & 2,290 & 67,836 & 025 \\
\hline \multirow{2}{*}{ Serin tutma } & E.V.A & 22,959 &, 000 & 3,369 & 98 & 001 \\
\hline & E.V.not A. & & & 2,989 & 50,346 & ,004 \\
\hline \multirow{2}{*}{ Hafiflik } & E.V.A & 1,353 & 248 & 870 & 98 &, 386 \\
\hline & E.V.not A. & & & 849 & 65,150 & ,399 \\
\hline \multirow{2}{*}{ Dökümlülük } & $\begin{array}{l}\text { E.V.A } \\
\end{array}$ & ,166 & ,685 & 2,222 & 98 & ,029 \\
\hline & E.V.not A. & & & 2,295 & 76,375 &, 024 \\
\hline
\end{tabular}

E.V.A.: Equal variances assumed; E.V.not A.:Equal variances not assumed

Çizelge 6'da verilen sig. sonuçlarına göre fiyat, dayanıklılık, rahatlık, hava geçirgenliği ve serin tutma davranışları üzerinde öğrencilerin vermiş oldukları cevaplar homojen değildir. Diğer sonuçlar içerisinden sig.2 tailed değerleri dikkate alındığında marka ve hammadde hususunda cinsiyetin belirleyici bir etken olmadığına karar verilebilir. Ancak kuruma ve dökümlülük üzerinde cinsiyet önemli bir parametredir. Bağımsız örnek ttesti sonuçlarına göre önemli çıkan anket soruları kız ve erkek öğrenci açısından değerlendirildiğinde Şekil 1 elde edilmiştir.

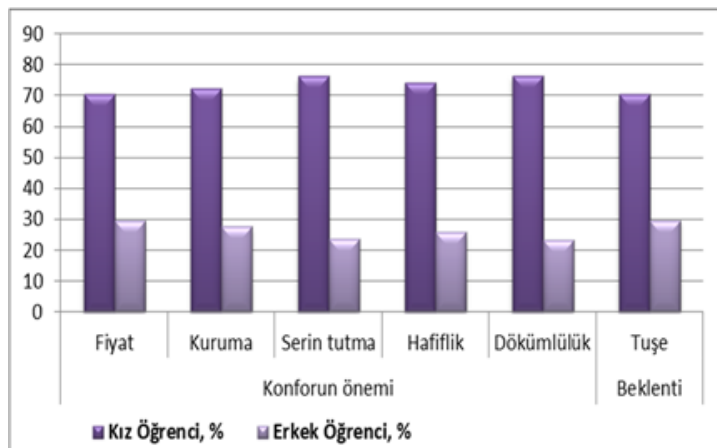

Şekil 1. Giysilerdeki konfora verilen önemin kızerkek öğrenci açısından değerlendirilmesi
Buradan hareketle giysinin tuşesi dışında erkek ve kız öğrencilerin kullanmış oldukları giyside önem verdikleri parametreler arasında anlamlı bir fark olmadığına kanaat edilebilir. Bunun nedeni olarak çağın getirmiş olduğu sosyo-ekonomik düzeyler ve sosyal iletişimden kaynaklanan giyinme arzusunun cinsiyetten bağımsızlaşması olarak düşünülmüştür. Giysi performansı ile cinsiyet arasında yapılan ttesti sonuçları Çizelge 7'de verilmektedir.

Çizelge 7. Giysi performans bağımsız örnek t-test

\begin{tabular}{|c|c|c|c|c|c|c|}
\hline & \multirow{2}{*}{\multicolumn{2}{|c|}{$\begin{array}{l}\text { Varyansların eşitliği } \\
\text { için Levene's testi }\end{array}$}} & \multirow{2}{*}{\multicolumn{3}{|c|}{$\begin{array}{c}\text { Cinsiyet } \\
\text { Ortalamaların eșitliği için t-testi }\end{array}$}} \\
\hline & & & & & & \\
\hline & & $\mathrm{F}$ & Sig. & $\mathrm{T}$ & Df & $\begin{array}{l}\text { Sig. }(2- \\
\text { tailed) }\end{array}$ \\
\hline \multirow{2}{*}{ Esneklik } & E.V.A. & ,618 &, 434 &, 762 & 97 &, 448 \\
\hline & E.V.not A. & & &, 745 & 65,817 & 459 \\
\hline \multirow{2}{*}{ Ter emicilik } & \begin{tabular}{|l|} 
E.V.A. \\
\end{tabular} & 1,331 & ,251 &,- 279 & 97 &, 781 \\
\hline & \begin{tabular}{|l} 
E.V.not A. \\
\end{tabular} & & &,- 291 & 78,613 & ,772 \\
\hline \multirow{2}{*}{ Hafiflik } & \begin{tabular}{|l|} 
E.V.A. \\
\end{tabular} &, 108 &, 743 & 1,289 & 97 & ,201 \\
\hline & $\begin{array}{l}\text { E.V.not A. } \\
\end{array}$ & & & 1,228 & 60,973 & ,224 \\
\hline \multirow{2}{*}{$\begin{array}{l}\text { UV } \\
\text { Dayanımı }\end{array}$} & \begin{tabular}{|l|} 
E.V.A. \\
\end{tabular} & 8,592 & ,004 &, 592 & 97 &, 555 \\
\hline & \begin{tabular}{|l} 
E.V.not A. \\
\end{tabular} & & &, 552 & 57,232 &, 583 \\
\hline \multirow{2}{*}{ Geçirgenlik } & \begin{tabular}{|l|} 
E.V.A. \\
\end{tabular} &, 504 &, 480 & 915 & 97 &, 362 \\
\hline & $\begin{array}{l}\text { E.V.not A. } \\
\end{array}$ & & & 900 & 66,765 &, 371 \\
\hline \multirow{2}{*}{$\begin{array}{l}\text { Vücuda } \\
\text { uygunluk }\end{array}$} & \begin{tabular}{|l|} 
E.V.A. \\
\end{tabular} & 2,118 &, 149 & ,680 & 97 & ,498 \\
\hline & $\begin{array}{l}\text { E.V.not A. } \\
\end{array}$ & & & ,638 & 58,313 &, 526 \\
\hline
\end{tabular}

E.V.A.:Equal variances assumed; E.V.not A.:Equal variances not assumed

Çizelge 7'deki sig. değerlerine göre UV dayanımı sorusuna verilen cevaplar homojen değildir. Diğer sorulara verilen cevaplar analiz edildiğinde 
cinsiyetin giysi performansıyla ilişkilendirilemeyeceği sonucu ortaya çıkmaktadır. Giysi sorunları ile cinsiyet arasında yapılan t-testi sonuçları Çizelge 8'de verilmiştir.

Çizelge 8. Giysi sorunları bağımsız örnek t-test

\begin{tabular}{|c|c|c|c|c|c|c|}
\hline & \multirow{2}{*}{\multicolumn{2}{|c|}{$\begin{array}{c}\text { Varyansların } \\
\text { eşitliği için } \\
\text { Levene's } \\
\text { testi } \\
\end{array}$}} & \multicolumn{3}{|c|}{ Cinsiyet } \\
\hline & & & & \multicolumn{3}{|c|}{$\begin{array}{l}\text { Ortalamaların eşitliği } \\
\text { için t-testi }\end{array}$} \\
\hline & & $\mathrm{F}$ & Sig. & $\mathrm{t}$ & Df & $\begin{array}{c}\text { Sig. } \\
(2-\text { tailed) }\end{array}$ \\
\hline \multirow{2}{*}{ Deformasyon } & E.V.A. & 1,444 & 232 & $-1,280$ & 97 & ,204 \\
\hline & E.V.not A. & & & $-1,240$ & 63,917 & ,220 \\
\hline \multirow{2}{*}{ Cilt Tahrişi } & E.V.A. & 033 & 857 &,- 922 & 97 & ,359 \\
\hline & E.V.not A. & & &,- 886 & 62,410 & ,379 \\
\hline \multirow{2}{*}{ Serinlik } & E.V.A. & ,063 & ,803 &,- 243 & 97 & ,808 \\
\hline & E.V.not A. & & &,- 241 & 68,001 & 810 \\
\hline \multirow{2}{*}{ icaklık } & $\begin{array}{l}\text { E.V.A. } \\
\end{array}$ & 8,619 & ,004 &,- 685 & 97 & ,495 \\
\hline & E.V.not A. & & &,- 620 & 52,917 &, 538 \\
\hline \multirow{2}{*}{ Terletme } & E.V.A. & 846 &, 360 & ,301 & 97 & ,764 \\
\hline & E.V.not A. & & & ,292 & 64,376 & 77 \\
\hline
\end{tabular}

E.V.A.: Equal variances assumed; E.V.not A.:Equal variances not assumed

Çizelge 8'de verilen sig. sonuçlarına göre sıcaklık dışındaki tüm sorulara verilen yanıtlar homojendir. Sonuçlar cinsiyet bazında incelenmiş ve cinsiyetin giysi sorunları üzerinde etkili olmadığına kanaat getirilmiştir. Giysi kullanımında öğrencilerin en sık karşılaştığı problemler cinsiyetten bağımsız olarak değerlendirildiğinde Şekil 2 ortaya çıkmaktadır.

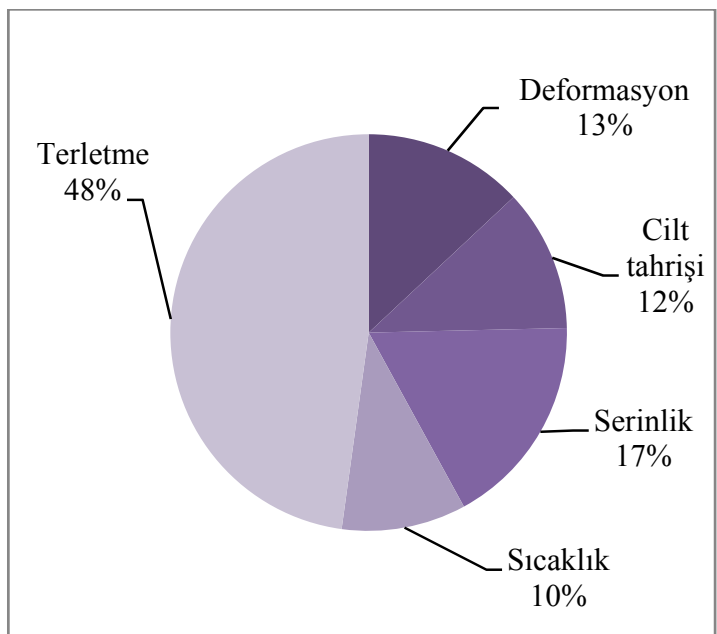

Şekil 2. Giysi kullanımında öğrencilerin en s1k karşılaştı̆̆ı sorunlar
Öğrencilerin giysi kullanırken en sık karşılaştığ1 sorunlar açısından değerlendirildiğinde terletmenin öğrenciler açısından en rahatsız edici problem olduğu ortaya konulmuştur. Giysi beklentileri ile cinsiyet arasında yapılan t-testi sonuçları Çizelge 9'da verilmiştir.

Çizelge 9. Giysi beklentileri bağımsız örnek t-test sonuçları

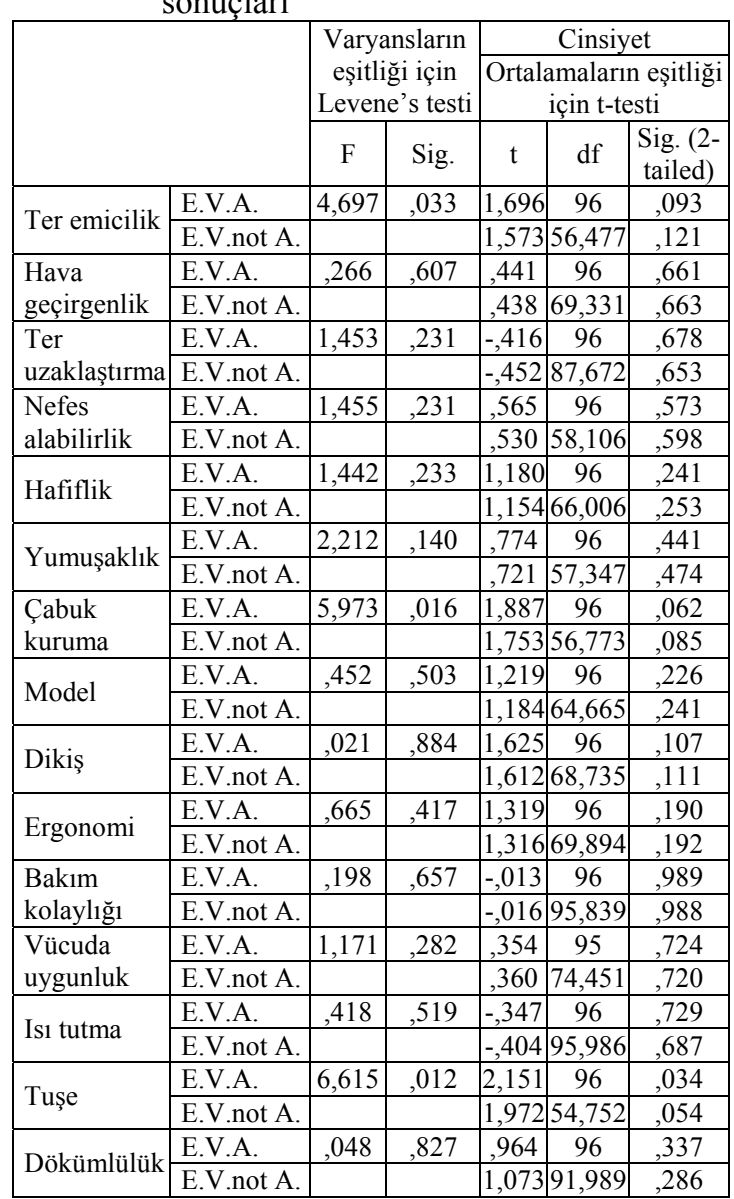

E.V.A.: Equal variances assumed; E.V.not A.:Equal variances not assumed

Çizelge 9 incelenmiş ve ter emicilik, çabuk kuruma ve tuşe dışındaki tüm soruların yanıtları homojendir. Test sonuçlarına göre cinsiyet giysi beklentileri üzerinde belirleyici bir etken değildir.

Ankette konforla ilişkili sorulara verilen "kesinlikle katılıyorum" cevabına istinaden beklentiler sıralaması kız ve erkek öğrenciler için Şekil 3'de gösterilmektedir. 


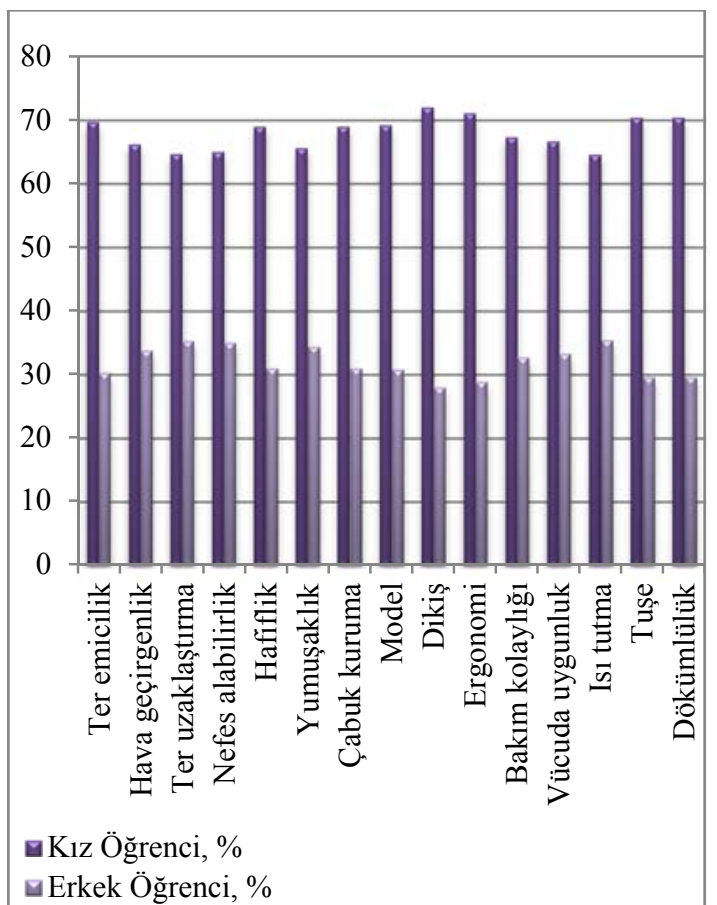

Şekil 3. Öğrencilerin giysilerden konfor açısından beklentileri

Şekil 3'e bakıldığında genel olarak öğrencilerin giysilerden konfor açısından beklentilerinin yüksek olduğu sonucuna varılmaktadır. Kız ve erkek öğrenciler açısından değerlendirildiğinde ise kız öğrencilerin dikiş, ergonomi, tuşe, dökümlülük ve ter emicilik parametrelerini, erkek öğrencilerin ise ter uzaklaştırma, nefes alabilirlik, yumuşaklık, 1Sı tutma, vücuda uygunluk ve bakım kolaylığı gibi parametreleri konfor açısından daha önemli bulduğu sonucuna varılmaktadır.

\section{SONUÇLAR}

Bu çalışma üniversitede eğitim gören kız ve erkek öğrencilerin konfor konusundaki farkındalıklarını farketmek amacıyla yapılmıştır. Çalışmada dört bölümden oluşan anket formu (giysi önemi, giysi performans1, giysi sorunları ve giysi beklentileri) kullanılmıştır. Soruların değerlendirilmesinde 3 ve 4 noktalı subjectif değerlendirme skalası kullanılmıştır. Sonuçlar matematiksel ve istatistiksel (cronbach ve bağımsız t-testi) olarak analiz edilmiştir. İstatistiksel veriler tablolar halinde sunulmuş ve gerekli kısımlarda grafiklerden yardım alınmıştır.

Sonuçlar matematiksel olarak ifade edildiğinde konfor açısından öğrencilerin en fazla hammadde, rahatlık ve dayanıklılı̆g önemsediği; serin tutma, fiyat ve hafifliği daha az önemsedikleri sonucuna varılmıştır. Giysi performansına bakıldığında ise öğrenciler için en önemli parametrenin vücuda uygunluk olduğu tespit edilmiştir. Öğrencilerden giysileri kullanırken karşılaştıkları sorunları ifade etmeleri istendiğinde deformasyon, cilt tahrişi, serinlik, sıcaklık ve terletmenin önemli ancak kişiden kişiye değişkenlik gösterdiği bulunmuştur. Giysilerden bekledikleri konfor parametreleri açısından ter emicilik, hava geçirgenliği, yumuşaklık ve isı tutma öğrencilerin en az \%60'ı için yüksek önem arz etmektedir.

Sonuçlar istatistiksel olarak analiz edildiğinde ise verilerin $\% 77$ oranında güvenilir olduğu sonucuna varılmıştır. Anket verilerinin cinsiyet açısından değerlendirilmesi için uygulanan bağımsız $\mathrm{t}$-test sonuçlarına göre;

- Marka ve hammadde hususunda cinsiyet belirleyici bir etken değildir.

- Cinsiyetin giysilerdeki konfor özelliklerinden kuruma ve dökümlülüğe verilen önem üzerinde bir etkisi vardır.

• Tuşe kızlar açısından önemli bir özelliktir.

- Giysi performans1 ve cinsiyet arasında önemli bir ilişki tespit edilememiştir.

- Kız ve erkek öğrencilerin giysiyle yaşadıkları problemler cinsiyetten bağımsızdır.

- Genel olarak bakıldığında öğrencilerin giysilerden konfor açısından beklentilerinin yüksek olduğu sonucu bulunsa da cinsiyetin bağımsız bir etken olduğu tespit edilmiştir.

$\mathrm{Bu}$ çalışmanın sonuçlarına göre gelişen sosyoekonomik ve kültürel düzey, kız ve erkek öğrenciler üzerinde benzer konfor arayışlarına sebep olmaktadır. 


\section{KAYNAKLAR}

1. Kahraman, C., Kaplan, S.. 2017. Çorap Konfor Performans Özellikleriyle İlgili Tüketici Beklentileri, Pamukkale University Journal of Engineering Sciences, 23(7), 818-825.

2. Aydın, S., Çileroğlu, B., 2006. İç Giyim Üretimine Yönelik 18-50 Yaşlar Arası Kadın Beden Ölçüleri Standardizasyonu, 12. Ulusal Ergonomi Kongresi, Ankara, Bildiriler Kitab1, 67-7.

3. Li, Y., 2001. The Science of Clothing Comfort, Textile Progress, UK, Woodhead, 31(1), 1-2, 1-135.

4. Öner, E., Okur, A., 2011. Materyal, Üretim Teknolojisi ve Kumaş Yapısının Termal Konfora Etkileri, The Journal of Textiles and Engineer, 80, 20-29.

5. Önder, E., Sarıer, N., 2006. Sicaklık Düzenleme İşi Olan Akıllı Tekstil Ürünlerinin Tasarımı, TÜBITTAK Proje No: MİSAG 238.

6. Arğıllı, E., 2011. Deri Üst Giyimine Yönelik Giysi Konforunun İncelenmesi, Gazi Üniv. Eğitim Bil. Enst. Giyim Endüstrisi ve Moda Bölüm. Yüksek Lisans Tezi.

7. Swinker, M.E., Hines, J.D., 2006. Understanding Consumers' Perception of Clothing Quality: A Multidimensional Approach, International Journal of Consumer Studies, 30, 218-223.

8. Akkuş, H., 2014. 44-56 Bedenler Arasındaki Bayan Tüketicilerin Giysi Satın Almada Figür Tipleri ve Beden Numaralarının Öneminin Incelenmesi, Marmara Üniversitesi Fen Bilimleri Enst., Yüksek Lisans Tezi.

9. Değirmenci, Z., Çelik, N., 2013. Örme Denim Kumaşların Tercih Edilmesi Üzerine Bir Araştırma, Tekstil Teknolojileri Elektronik Dergisi, 7(2), 16-26.

10. Gitimu, N.P., Workman, J., Robinson J.R., 2013. Garment Quality Evaluation: Influence of Fashion Leadership, Fashion Involvement, and Gender, International Journal of Fashion Design, Technolog and Education, 6(3), 173-180.

11. Hourigan, S.R., Bougoure, U., 2012. Towards a Better Understanding of Fashion Clothing
Involvement. Australasian Marketing Journal, 20(2), 127-135.

12. Kamineni, R., 2005. Influence of Materialism, Gender and Natioanality on Consumer Brand Perceptions. Journal of Targetting, Measurement \& Analysis for Marketing, 14(1), 25-32.

13. Wu, J., Delong, M., 2006. Chinese Perception of Western-branded Denim Jeans: A Shangai Case Study". Journal of Fashion Marketing and Management, 10(1), 238-250.

14. Kaplan, S., 2009. Kumaşların Mekanik Özelliklerinden ve Geçirgenlik Özelliklerinden Yararlanilarak Giysi Konforunun Tahminlenmesi. Dokuz Eylül Üniversitesi, İzmir, Türkiye. Doktora Tezi.

15. Das, A., Alagirusamy, R., 2010. Science in Clothing Comfort. India, New Delhi, Woodhead Publishing.

16. Song, G., 2011. Improving Comfort in Clothing. Cambridge, England, Woodhead Publishing. 